\title{
Utilization of planting white oyster mushroom media wastes (Pleurotus ostreatus) fermented by starbio on local sheep male performances
}

\author{
T S Simorangkir, T H Wahyuni, M Tafsin, I Sembiring, N Ginting \\ Animal Production Program, Faculty of Agriculture, University of North Sumatra, \\ Medan 20155, Indonesia \\ E-mail : simorangkirt2@gmail.com
}

\begin{abstract}
The Utilization of Planting White Oyster Mushroom Media Wastes (Pleurotus ostreatus) fermented by Starbio on Local Sheep male Performances. White osyter mushroom media waste is one of agricultural waste can be utilized sheep.The research have been conducting for 3 month ago. The purpose of this research is to find out and learn the influence of the use of white osyter mushroom media waste in fermentation with starbio performances on male local sheep. This study used 20 male local sheep. The method used was a complete randomized design which consist of four treatments and five replications. The treatment consists of 4 types with utilization of planting white oyster mushroom media wastes different $\mathrm{P} 0, \mathrm{P} 1, \mathrm{P} 2$, and $\mathrm{P} 3$ are $0 \%$, $10 \%, 20 \%$, and $30 \%$ respectively. The result of this reseacrh showed that P0, P1, P2, and $\mathrm{P} 3$ treatment were significanly differences $(\mathrm{P} \leq 0,01)$ in feed consumption, average daily gain but had no significanly $(\mathrm{P} \geq 0,05)$ in feed convertion ration ration. Based on this research can be concluded that the utilization of media wastes planted white oyster mushroom (Pleurotus ostreatus) fermented by Starbio on $10 \%$ level increase feed consumption, average daily gain and income over feed cost local sheep male.
\end{abstract}

\section{Introduction}

Sheep is an animal that is broad known by the community as one of the livestock that lives in the tropics which generally has several advantages, namely as a producer of milk and meat, and its feces can be used as a source of organic fertilizer and its skin has high economic value.

But there are still some important factors that influence the success of livestock farming, one of which is the continuity of feed availability. Forage production generally fluctuates according to the seasonal pattern, in rainy season is abundant and in the dry season is very limited. Efforts to increase forage production by expanding land are an alternative, but in reality there is competition with the expansion of food crops and buildings/settlements. Efforts to find alternative feed sources are very necessary with rational considerations, cheap and easy to obtain and available throughout the year. One of alternative to overcome the shortage of forages is by utilizing the results of agricultural crop residues.

Planting white osyter mushroom media wastes is one of the many agricultural waste which is not yet used as alternative livestock feed ingredients. The waste of white oyster mushroom planting media is just thrown away, whereas when viewed from its constituent material, the waste can be used as ruminant feed especially as a source of fiber substitute for corn cobs which is expected to be able to supply energy needs for livestock that consume it.

Ingredients or planting media of white osyter mushroom in the form of sawdust, rice bran is not all used up when used to produce white osyter mushroom, but there are still remnants that are no longer effective for producing white osyter mushroom properly. Judging from the constituent ingredients, the 
waste of planting media of white osyter mushroom can still be used as animal feed, especially ruminants.

However, the low crude protein content and high crude fiber in the white osyter mushroom planting media waste need to be fermented to increase the crude protein content and reduce the crude fiber content in the waste. The fermentation process is the process of decomposing the organic elements of a group, especially carbohydrates to produce an energy through the work system of enzymes produced by microorganisms. The fermentation process is a process of "protein enchirment" which means the process of enriching material protein by using certain microorganisms. One of the microorganisms that can be used is starbio. The use of starbio in feed causes bacteria that are in starbio to help break the tissue structure that is difficult to decompose so that more nutrients can be absorbed and transfor med into livestock products. In addition, livestock productivity will increase, even more nutrients can be broken down and absorbed Samadi [1]. After the fermented planting media waste uses starbio, there is an increase in crude protein and a decrease in crude fiber.

This is what underlies the potential of the planting media of white oyster mushroom wastes as an alternative animal feed material for further study.

\section{Material and Methods}

This research have been conducted starting for 12 weeks starting from January to March 2018 in Blok II Payabakung Village, Hamparan Perak District, District Deli Serdang, North Sumatera.

The materials used were 20 head local male sheep, white oyster mushroom media waste which obtained around the location of white oyster mushroom cultivation, probiotic Starbio ${ }^{\circledR}$, molasses, rice bran, urea, water sufficiently, tarpaulin as a placefor mix waste of white oyster mushroom media, medicine, rhodallon, drums, shovels, scales, lamps, plastic sheeting.

The experimental design used in this study was completely randomized design with 4 treatments in the form of fermentation length and 5 replications. The treatment is as follows :

P0 : Without oyster mushroom media wastes fermented (control)

P1 : 10\% fermented white oyster mushroom media wastes

P2 : $20 \%$ fermented white oyster mushroom media wastes

P3 : 30\% fermented white oyster mushroom media wastes

\subsection{Feed Consumption.}

Feed consumption (g/head/day) is calculated every day based on the difference between the amount of feed given and the amount of leftover food. Can be formulated as follows:

Feed Consumption $=$ Early Feed - Leftover Feed

\subsection{Average Daily Gain}

Average daily gain ( $\mathrm{g} / \mathrm{head} /$ day) is calculated every two weeks based on the difference between weighing the final body weight and weighing the initial body weight. Can be formulated as follows:

Average Daily Gain = Final Body Weight - Initial Body Weight

\subsection{Feed Conversion Ration}

Feed conversion ration is calculated by comparing the amount of feed consumed with the weight gain achieved every week based on the measurement of the place and the value obtained. Can be formulated as follows:

Feed Conversion Ration $=$ Feed Consumption

Average Daily Gain

\subsection{Income Over Feed Cost}

The main objective in a farm is to get a profit, therefore there is a need for economic analysis in sheep farming. One economic analysis that can be used is income over feed cost (IOFC), namely income received after deducting feed costs during maintenance Mulyaningsih [2]. The cost of feed is one of 
the most important factors in sheep fattening business which can reach around $70 \%$ of the production costs, so that efficient feed will provide great economic benefits.

\section{Results and Discussion}

Table 1. Recapitulation of research results of the utilization of planting white oyster mushroom media wastes (Pleurotus ostreatus) fermented by starbio on local sheep male performances.

\begin{tabular}{lcccc}
\hline & \multicolumn{4}{c}{ Parameters } \\
\cline { 2 - 5 } Treatments & $\begin{array}{c}\text { Feed } \\
\text { Consumption } \\
(\mathrm{g} / \mathrm{head} / \text { day })\end{array}$ & $\begin{array}{c}\text { Average Daily } \\
\text { Gain } \\
(\mathrm{g} / \text { head/day })\end{array}$ & $\begin{array}{c}\text { Feed } \\
\text { Conversion } \\
\text { Ration }^{(\mathrm{tn})}\end{array}$ & $\begin{array}{c}\text { IOFC } \\
(\text { Rp/head/12/weeks })\end{array}$ \\
\hline P0 & $714,85^{\mathrm{b}}$ & $64,52^{\mathrm{bc}}$ & 11,13 & $159.672,74$ \\
P1 & $855,33^{\mathrm{a}}$ & $82,14^{\mathrm{a}}$ & 10,45 & $209.207,81$ \\
P2 & $772,42^{\mathrm{ab}}$ & $71,19^{\mathrm{b}}$ & 10,85 & $174.035,13$ \\
P3 & $662,22^{\mathrm{b}}$ & $58,57^{\mathrm{c}}$ & 11,34 & $136.861,51$ \\
\hline
\end{tabular}

Description: Superscript with different letters in the same column shows a significant different effect $(\mathrm{P}>0.01)$.

\subsection{Feed Consumption}

Based on Table 1. it can be seen that the highest difference in consumption of ration dry matter in rams was given in the treatment of $\mathrm{P} 1$ which was $10 \%$ of the planting media waste of white oyster mushroom fermented with starbio in the ration which was $855.33(\mathrm{~g} / \mathrm{head} /$ day $)$, followed by in treatment P2 that is giving $20 \%$ of the planting media waste of oyster mushroom fermented with starbio in the ration that is equal to 772.42 (g/head/day), followed by treatment $\mathrm{P} 0$, which is without giving planting white osyter mushroom media wastes with starbio in the ration which is equal to 714.85 (g/head/day), and the lowest in P3 treatment, namely giving 30\% of the planting media waste of oyster mushroom fermented with starbio in the ration which is $662.22(\mathrm{~g} / \mathrm{head} / \mathrm{day})$. The results of the analysis of variance showed that the administration of starbio-fermented oyster mushroom growing media showed an effect that was significantly different $(\mathrm{P}<0.01)$ on the consumption of ration dry matter in male local sheep. From the Duncan test results showed that the P1 treatment was not significantly different from $\mathrm{P} 2$ but was significantly different from treatment $\mathrm{P} 0$ and $\mathrm{P} 3(\mathrm{P}<0.01)$. Whereas P1 treatment was not significantly different from treatment P0 and P3.

Feed consumption content of utilization of planting white oyster mushroom media wastes (Pleurotus ostreatus) fermented by starbio on local sheep male can be seen in Figure 2 below:

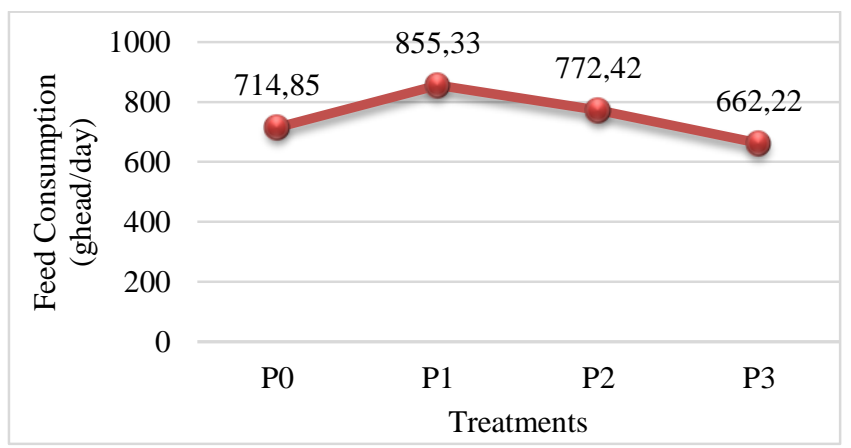

Figure 1. Graph of feed consumption of dry matter rations using fermented white media (Pleurotus ostreatus) planting media waste using starbio in rations on male local sheep performance 
The results of the overall ration feed consumption study above shows that there are differences in each treatment. There is an increase in the amount of ration consumption at the level of $10 \%$ of the planting media waste of oyster mushroom fermented with starbio in the ration and decreases starting at the level of $20 \%$ of the planting media waste of oyster mushroom fermented with starbio in the ration. This is influenced by the waste of planting media with starbio fermented oyster mushroom has a pungent odor that is not tasty and the texture of the waste of planting media of oyster mushroom in the form of fine particles such as bran makes the sheep do not like it. The giving of planting media waste of oyster mushroom fermented with starbio in the ration caused a decrease in ration dry matter consumption at the level of 20\%. This is in line with Prasetyo [3] opinion which states that the factors that influence consumption are livestock palatability to the ration given and the opinion of Soebarinoto et al [4] that the physical form of a feed ingredient can affect the palatability of the feed ingredients. Palatitability is an important factor that determines the level of feed consumption and depends on smell, taste, texture or shape, and temperature.

\subsection{Average Daily Gain.}

Based on Table 1 it can be seen that the highest average daily gain of local male sheep was found in $\mathrm{P} 1$ treatment which was 82.14 (g/ head/ day), followed respectively in P2 treatment which was 71.19 (g/ head/ day), in treatment P0 that is equal to $64.52(\mathrm{~g} / \mathrm{head} /$ day), and in treatment $\mathrm{P} 3$ that is equal to $58.57(\mathrm{~g} / \mathrm{head} / \mathrm{day})$. The results of the analysis of variance showed that the use of the planting white osyter mushroom media wastes with starbio in the livestock ration to daily average daily gain was very significantly different $(\mathrm{P}<0.01)$. There is a difference in the daily average daily gain of male local sheep affected by the giving of different levels of waste media for planting oyster mushroom fermented with starbio. Duncan's test results showed that P1 treatment was very significantly different from treatment $\mathrm{P} 0, \mathrm{P} 2$, and $\mathrm{P} 3$. The treatment of $\mathrm{P} 2$ was not significantly different from the treatment of P0 but was significantly different from the treatment of P3.

Average daily gain content of utilization of planting white osyter mushroom media wastes (Pleurotus ostreatus) fermented by starbio on local sheep male can be seen in Figure 2 below:

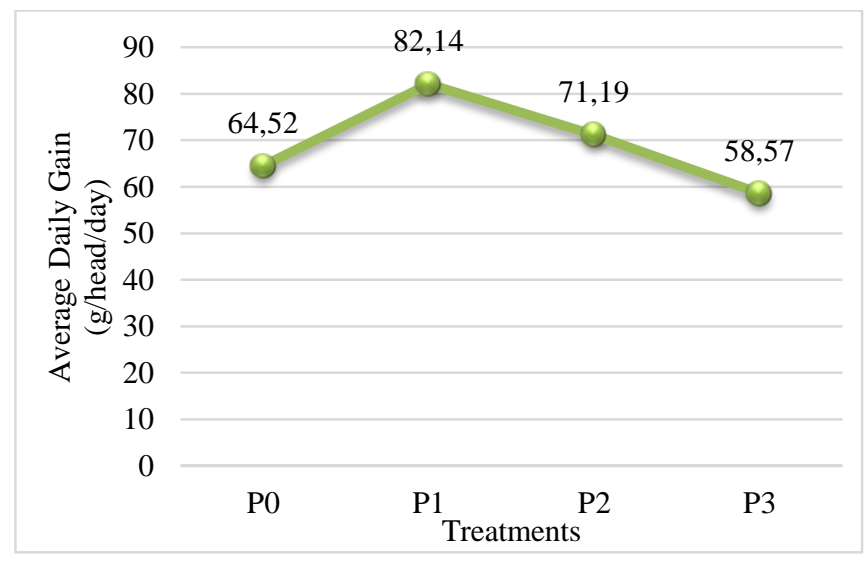

Figure 2. Graph of average daily gain of the waste media using the white oyster mushroom (Pleurotus ostreatus) which is fermented using starbio in the ration to the performance of the male local sheep.

The graph of average gain shows that there is an increase in the average daily gain rate in treatment P1 $(82,14)$ and decreases in treatment P2 $(71,19)$ and P3 $(58,57)$. This is influenced by different nutrient content in each treatment and also the amount of consumption in P1 treatment is higher than P0, P1, and P3. The giving of $30 \%$ fermented white osyter mushroom planting media waste into the ration causes a decrease in the daily average daily gain of male local sheep. Feed consumption by livestock is positively correlated to average daily gain. This is consistent with the opinion of Kartadisastra [5] which states that livestock weight gain is directly proportional to the level of consumption. The higher 
the level of consumption, the higher the body weight and Syamsuhaidi [6] which states that high feed consumption will be followed by better average daily gain. This is also caused by a variety of possibilities, namely the difference in protein content in each treatment from the results of the ration arrangement so that the nutrients that will be used in body weight are getting less. This is also consistent with Anggorodi [7] opinion, a nutrient that affects growth is protein. Protein is a constituent of most of the tendons, organs, cartilage and outer and inner connective tissue. Crude protein that enters the body will be used by livestock to replace damaged body tissue and for growth.

Average daily gain in sheep in P1 treatment, namely giving fermented mushroom planting media with starbio in ration at $10 \%$ level was 82.14 . This is not much different from the results of the study Ana et al [8] which states that average daily gain with a $15 \%$ mushroom media level is 82.54 . This is also not much different from the results of the study Kennedy [9] which states that local sheep average daily gain fed $30 \%$ corn cobs, coconut cake and soybean meal is 73.35 .

\subsection{Feed Conversion Ration}

Table 1 shows that feed convertion ration in treatment $\mathrm{P} 0$ is $11.13, \mathrm{P} 1$ is $10.45, \mathrm{P} 2$ is 10.85 , and $\mathrm{P} 3$ is 11.34. Where the total average conversion ratio for twelve weeks is 10.95 , which means that to increase 1 gram of body weight requires a ration of 10.95 grams of ration in dry matter. This is also in accordance with the results of the study Kennedy [9] which states that the conversion of local sheep fed corn cobs is 11.1-12.8.

The results of the analysis of variance showed that the use of fermented mushroom with starbio in the cattle ration on feed convertion ration was not significantly different $(\mathrm{P}>0.05)$. Feed convertion ration that is not significantly different is caused by the presence of good average daily gain, good ration consumption. This is consistent with the opinion of Martawidjaya [10] who argued that ration conversion, especially in ruminant livestock, is affected by feed quality, the amount of average daily gain and digestibility value.

\subsection{Income Over Feed Cost (IOFC)}

The main components that are considered from this calculation are the selling price of the sheep, the purchase price and the cost of feed. Other costs incurred during the livestock raising process are not taken into account in the IOFC system. The selling price and buying price of sheep are used based on the prevailing prices on the farms of the research location. The price of the sheep used for fattening is Rp.50,000,000/ kg of live weight. Feed prices in treatment P0, P1, P2, and P3 are 1854, 1890, 1926, 1962.

Income over feed cost content of utilization of planting white oyster mushroom media wastes (Pleurotus ostreatus) fermented by starbio on local sheep male can be seen in Figure 3 below:

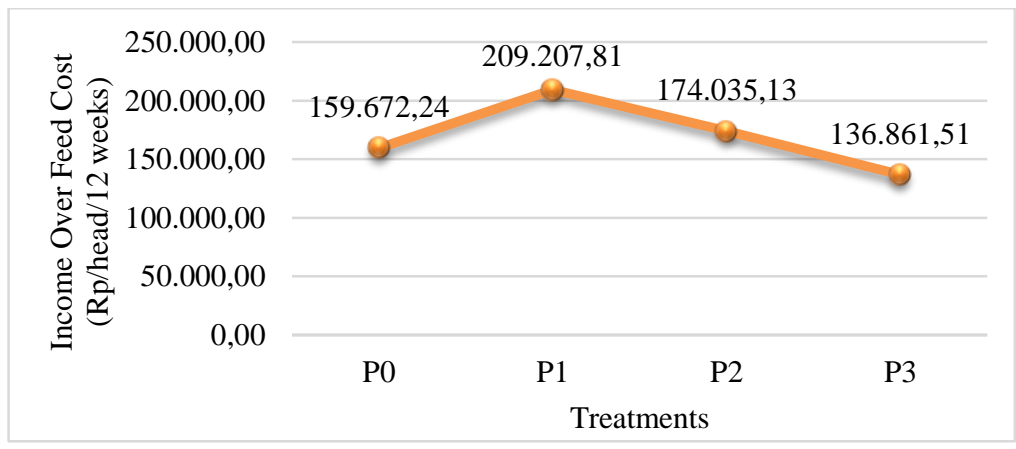

Figure 3. Graph of Income over feed cost for using waste of planting media for white oyster mushroom (Pleurotus ostreatus) which is fermented using starbio

The initial body weight will be average in treatment P0, P1, P2, and P3 is $12.80,13.88,13.68$, and 13.68. The average body weight of the end of maintenance is $\mathrm{P} 0, \mathrm{P} 1, \mathrm{P} 2$, and $\mathrm{P} 3$, which are 18.48 , 
20.78, 19.66 and 18.22. The average feed consumption in each treatment was $60.05 \mathrm{~kg}, 71.85 \mathrm{~kg}$, $64.88 \mathrm{~kg}$, and $55.63 \mathrm{~kg}$. The lowest feed costs incurred during maintenance are in the P3 treatment compared to treatment $\mathrm{P} 0, \mathrm{P} 1$, and $\mathrm{P} 2$, due to the low consumption of $\mathrm{P} 3$ treatment.

The data above shows that the treatment that gives the most benefit is the treatment of P1. This is influenced by good average daily gain so that the acceptance is even higher. This is consistent with the opinion of Rasyaf [11] which states that the higher the IOFC value, the better maintenance will be carried out, because the high IOFC means that the revenue obtained from the sale of chickens is also higher.

\section{Conclusion}

The giving of fermented white oyster mushroom planting media wastes starting from $20 \%$ decreases male local sheep average daily gain. The use of starbio-fermented mushroom growing media on oyster mushroom at a level of $10 \%$ can increase feed consumption, the rate of livestock weight gain and income over feed cost (IOFC) of local male sheep.

\section{References}

[1] Samadi. 2007. Probiotik Pengganti Antibiotik dalam Pakan Ternak. Fakultas Pertanian Program Studi Peternakan Universitas Syah Kuala Banda Aceh.

[2] Mulyaningsih, T. 2006. Penampilan domba ekor tipis (Ovies aries) jantan yang digemukkan dengan beberapa imbangan konsentrat dan rumput gajah (Pennisetum purpureum). Skripsi. Fakultas Peternakan. Institut Pertanian Bogor. Bogor

[3] Prasetyo, H. 2012. Pedoman Penggemukan Babi Secara Intensif. Pustaka Baru Press. Edisi Pertama. Yogyakarta.

[4] Soebarinoto, S. Chuzaemi, dan Mashudi. 1991. Ilmu Gizi Ruminansia. Jurusan Nutrisi dan Makanan Ternak, Universitas Brawijaya Malang.

[5] Kartadisastra, H.R., 1997. Pakan Ternak Ruminansia. Kanisius. Yogyakarta.

[6] Syamsuhaidi. 1997. Penggunaan Duckweed (Familiy lemnaceae) Sebagai Pakan Serat Sumber Protein Dalam Ransum Ayam Pedaging. Disertasi. Program Pascasarjana Institut Pertanian Bogor. Bogor.sss

[7] Anggorodi, R. 1990. Ilmu Makanan Ternak. PT. Gramedia. Jakarta.

[8] Ana, R.T., D. Heriyadi., UH. Tanurwiria., D. Mulyanti. Pemberian Berbagai Level Limbah Media Jamur Tiram Putih (Pleurotus ostreatus) Terhadap Performa Domba Garut. Fakultas Peternakan.Universitas Padjajaran. Jatinamgorgrina. 2009. Budidaya Jamur Tiram. Penebar Swadaya. Jakarta.

[9] Kennedy, I.L.M. Performa Domba Lokal Jantan Yang Mendapat Sumber Serat Tongkol Jagung Dengan Beberapa Kombinasi Sumber Protein. 2012. Fakultas Peternakan. Institut Pertanian Bogor.

[10] Martawidjaya, M., B Setiadi dan S. S Sitorus. 1999. Pengaruh Tingkat Protein Energi Ransum Terhadap Kinerja Produksi Kambing Kacang Muda, Balai Penelitian Ternak, Jurnal Ilmu Ternak dan Veteriner 4.

[11] Rasyaf, M. 2011. Panduan Beternak Ayam Pedaging. Cetakan ke-4. Penebar Swadaya. Jakarta. 